\title{
Respiratory syncytial virus replication induces Indoleamine 2,3-dioxygenase (IDO) activation in human dendritic cells
}

\author{
Farnam Ajamian*, Yingqi Wu, Francis Davoine, Redwan Moqbel, Darryl J Adamko \\ From AllerGen NCE Inc.'s Fifth Annual Research Conference: Innovation from Cell to Society \\ Québec City, QC, Canada. 7-9 February 2010
}

\section{Objective/purpose}

Induction of IDO in dendritic cells (DCs) depletes the essential amino acid, tryptophan, and generates a family of catabolites known as kynurenines (KYN). IDO activity is reported to have immunomodulatory effects, including the selective induction of apoptosis in T-helper 1 (Th1) lymphocytes, an effect not seen with Th2 cells that are dominant in allergic asthma. Infants hospitalized for RSV-related bronchiolitis have increased risk of developing asthma ( $48 \%$ vs. $8 \%$ in control). Induction of IDO activity by RSV may explain the link between RSV bronchiolitis and asthma pathogenesis. IDO is induced by various cytokines and a number of non-airway viruses; however, RSV has not yet been studied. We hypothesize that RSV induce IDO activation in human dendritic cells (DCs).

\section{Methods}

Primary human dendritic cells (DCs) were infected with sucrose gradient purified RSV with a multiplicity of infection (MOI) rate of 1.0. Flow cytometry and confocal microscopy were used to confirm infection. We measured KYN in culture media by a spectrophotometric method using Ehrlich reagent. We blocked RSV infection with the RSV-mAb, Palivizumab, and UV-inactivation to determine a role for infection. The potent competitive inhibitor of viral RNA polymerase, Ribavirin, was used to block RSV replication and protein synthesis. To evaluate dependency of RSV-induced IDO induction on different cell signaling pathways, we used a variety of specific inhibitors including MEK inhibitor I (120 nM), MEK inhibitor II (4 $\mu \mathrm{M})$, SB202190 (p38MAPK, $3 \mu \mathrm{M})$, JNK inhibitor II $(1 \mu \mathrm{M})$, IKK inhibitor II

University of Alberta, Canada
(Wedelolactone, $30 \mu \mathrm{M}$ ), IKK inhibitor III (BMS345541, $3 \mu \mathrm{M}$ ) and relevant negative controls.

\section{Findings}

DCs incubated with RSV showed a 35\% shift in flow cytometry compared to uninfected control DCs $(n=12)$ thus confirming infection of DCs. KYN, as a marker of IDO induction, was increased 13.2 fold in supernatants of infected DCs compared with control DCs (43.6 vs. $3.3 \mu \mathrm{M}, \mathrm{n}=6$ ). Inactivation of virus by Palivizumab or UV resulted in 99\% decrease in levels of KYN compared to controls $(\mathrm{n}=3)$. Infecting DCs with higher MOI of UV-inactivated RSV (up to $20, \mathrm{n}=3$ ) did not induce IDO. Addition of Ribavirin to culture media reduced KYN release in a dose-dependent manner with $50 \%$ reduction at $220 \mu \mathrm{M}(\mathrm{n}=3)$, without having any blocking effect on positive controls (IFN- $\gamma$ induced KYN release) at similar concentrations. Except for SB202190, none of the specific inhibitors of signaling pathway including NF- $\kappa \mathrm{B}$, JNK-MAPK and MEK/ERK-MAPK showed any significant inhibitory effect on IDO induction by RSV $(\mathrm{n}=3)$. SB202190, the specific inhibitor of P38-MAPK, blocked 51\% $\left(\mathrm{IC}_{50}=300 \mathrm{nM}\right)$ and $92 \%(3$ $\mu \mathrm{M})$ of KYN release $(\mathrm{n}=3)$; negative controls showed no inhibitory effect.

\section{Deliverables}

Our data showing IDO to be induced in DCs following infection with RSV is novel. Further, the observation that induction was dependent on viral replication was unexpected. Although NF- $\kappa \mathrm{B}$ is reported to have a role in IDO induction, our data suggest that RSV-induced kynurenine release may occur through an NF- $\kappa \mathrm{B}$-independent pathway. 


\section{Relevance}

These data support our hypothesis that RSV plays a role in the development of an immune response towards a Th2 pattern. Prevention of RSV infection could decrease the incidence of asthma. We expect to be publishing these novel findings in 2010.

Published: 26 November 2010

doi:10.1186/1710-1492-6-S3-P8

Cite this article as: Ajamian et al:: Respiratory syncytial virus replication induces Indoleamine 2,3-dioxygenase (IDO) activation in human dendritic cells. Allergy, Asthma \& Clinical Immunology 2010 6(Suppl 3):P8.

Submit your next manuscript to BioMed Central and take full advantage of:

- Convenient online submission

- Thorough peer review

- No space constraints or color figure charges

- Immediate publication on acceptance

- Inclusion in PubMed, CAS, Scopus and Google Scholar

- Research which is freely available for redistribution

Submit your manuscript at www.biomedcentral.com/submit 